\title{
The Frequency and Spectrum of Bacterial Contamination of Packed Red Blood Cells and Platelet Concentrate Units from a Sample of Iraqi Blood Donors
}

\author{
Ali Khazaal Jumaa ${ }^{1 *}$, Haider Hasan Jaleel Al-Shammari² and Zaynab Raad Qasim³ \\ ${ }^{1}$ Internal Medicine Department, College of Medicine, University of Basrah, Basrah, Iraq \\ ${ }^{2}$ Department of Pathology and Forensic Medicine, College of Medicine, University of Baghdad, Baghdad, Iraq \\ ${ }^{3}$ Basrah Hematology Center, Basrah Health Directorate, Ministry of Health/Environment, Basrah, Iraq
}

\begin{abstract}
Bacterial contamination of donated blood is defined as the presence of bacteria in the blood components which are collected and/or processed for transfusion. It is the second cause of death beyond ABO-mismatch. The aims were to determine the frequency of bacterial contaminations in stored packed RBC and platelet concentrate units. This cross-sectional study was conducted in Baghdad between $2^{\text {nd }}$ of September to $27^{\text {th }}$ of December 2019. Two hundred samples; 100 samples from packed RBC units and 100 samples from platelet concentrate units were randomly selected. There were $38 / 100$ of platelet concentrate units found to be contaminated, while 28/100 samples studied of packed RBC units were contaminated by bacteria. The high rate of contamination of samples presented. Gram-positive bacteria were the most predominant, and this attributed to poor skin cleansing and antiseptic techniques used prior to donor blood collection.
\end{abstract}

Keywords: blood donors; bacterial contamination; packed red blood cells; transfusiontransmitted bacterial infection

\section{INTRODUCTION}

The protection of transfused blood from microbial contaminants is mandatory (Walther, 2008). When the bacteria isolated from both the blood product and the transfused recipient, this called definite cases, but when the recipient's blood is either not cultured or negative, this called probable cases (Perez et al., 2001). If there are no bacteria isolated from the blood product and the recipient is positive, these called possible cases (Perez et al., 2001). The donated blood contamination may happen from two routes are endogenous or exogenous (Cawley et al., 2011; Arewa, 2009). The higher risk for bacterial contamination is among platelets concentrate units (Eder et al., 2017). Transfusion-transmitted bacterial infection (TTBI) associated with a wide spectrum of microorganisms (Perez et al., 2001).
The aims were to determine the frequency and bacterial contaminations spectrum in stored packed RBC and platelet concentrate units.

\section{MATERIALS AND METHOD}

\section{A. Study Design and Setting}

A cross-sectional study was conducted in the National Blood Transfusion Center between $2^{\text {nd }}$ of September to $27^{\text {th }}$ of December 2019.

\section{B. Donor Selection}

The samples were collected, processed and separated into packed red cells, platelet concentrate and plasma within 8 hours. Donor's blood that tested positive for transfusion transmissible infections (mainly HIV, HBV, HCV, and Syphilis), and expired blood components were excluded. 


\section{Storage Conditions}

In the National Blood Transfusion Center (NBTC), blood components are stored in well-monitored and controlled temperature equipment as: blood storage refrigerators from $\left[1^{\circ} \mathrm{C}\right.$ to $\left.6^{\circ} \mathrm{C}\right]$ for red blood cells, a platelet incubator and agitator from $\left[20^{\circ} \mathrm{C}\right.$ to $\left.24^{\circ} \mathrm{C}\right]$.

\section{Sample Size}

Two hundred samples were included in this study, 100 samples from packed RBC units and 100 samples from platelet concentrate units.

\section{E. Collection and Transportation of Samples}

By using standard bacteriological safety and standard aseptic techniques, all samples were processed, transported, and analyzed. Stored packed RBC and platelet concentrate were mixed, and the end of the enveloped tubes were chosen as a site for puncture (Brecher \& Hay, 2005).

BacT/ALERT culture bottles are disposable culture bottles that contain $30 \mathrm{ml}$ of complex medium and adsorbent polymeric beads. Whereas the medium consist of the following reactive components: a combination of peptones/biological extracts, anticoagulant, vitamins and amino acids. These culture media are used for quality control testing as they support the growth of aerobic microorganisms (bacteria and fungi).

\section{F. Procedure}

Packed RBC and platelets concentrate were cultured utilizing standard methods onto culture media include: Blood (BA), MacConkey (MA), Mannitol salt (MSA), and Urinary tract infection (UTI) agars. Well isolated colonies (3-5) were transferred to glass tube contain ( $3 \mathrm{ml}) \mathrm{DW}$ to measured and adjusted turbidity that represent bacterial cells number per $(1 \mathrm{ml})$ which must be equal to (0.55-0.65 optical density) by DensiCHEK Plus device. Then, swabbed with positive results were further processed in VITEK 2 compact system (bioMérieux, France).

\section{G. Statistical Methods}

Interpretation of results was performed according to VITEK 2 compact system special software to identify bacterial species and strains.

\section{RESULT AND DISCUSSION}

About 38/100 (38\%) platelet concentrate units were found to be contaminated by bacteria. The Gram positive bacteria were the predominant $30(79 \%)$ vs $8(21 \%)$. Bacillus subtilis was the most frequent $24 / 38$ (63\%), followed by Staphylococcus epidermidis 6/38(16\%), Escherichia coli 4/38(10.5\%), Proteus mirabilis 2/38(5.2\%), and Pseudomonas aeruginosa 2/38(5.2\%), as shown in Table 1.

Table 1. Bacterial contamination in platelet concentrate units

\begin{tabular}{|c|c|c|c|c|c|}
\hline Bacterial growth & No. (\%) & Gram stain & No. (\%) & Bacteria & No. (\%) \\
\hline \multirow[t]{5}{*}{ Detected growth } & $38(38 \%)$ & G +ve bacteria & $30(79)$ & Bacillus subtilis & $24(63)$ \\
\hline & & & & S. epidermidis & $6(16)$ \\
\hline & & $\mathrm{G}$-ve bacteria & $8(21)$ & E. coli & $4(10.5)$ \\
\hline & & & & Proteus mirabilis & $2(5.2)$ \\
\hline & & & & P. aeruginosa & $2(5.2)$ \\
\hline No growth & $62(62 \%)$ & - & - & - & - \\
\hline
\end{tabular}


About 28/100 (28\%) packed RBC units were found to be 5/28(18\%), and Staphylococcus epidermidis 4/28(14.2\%), contaminated by bacteria. The Gram positive bacteria were the as shown in Table 2. predominant $23(82 \%)$ vs 5 (18\%). Bacillus subtilis was the most frequent 19/28(67.8\%), followed by Escherichia coli

Table 2. Bacterial contamination in packed RBC units

\begin{tabular}{lccccc}
\hline Bacterial growth & No. (\%) & Gram stain & No. (\%) & Bacteria & No. (\%) \\
\hline $\begin{array}{l}\text { Detected } \\
\text { growth }\end{array}$ & $28(28)$ & G +ve & $23(82)$ & Bacillus subtilis & $19(67.8)$ \\
& & & & S. epidermidis & $4(14.2)$ \\
& & G -ve & $5(18)$ & E. coli & $5(18)$ \\
No growth & $72(72)$ & - & - & - & - \\
\hline
\end{tabular}

In this study, the overall rates of bacterial contamination of packed RBC and platelet concentrate were $38 \%$ and $28 \%$, respectively. Those were much higher than that recorded by similar studies in other countries like Egypt: 17.9\% (Samia et al., 2014), Ethiopia: 9.2\% (Agzie et al., 2019), Uganda: 3.5\% (Aloysius, 2013), USA: 0.2\% (Kuehnert et al., 2001), UK: 0.15\%, (Williamson et al., 1999), and France: 0.1\% (Wanger et al., 1994). This could be attributed to poor infrastructure setup and practice of infection control standards, including lack of thorough inquiry about any recent febrile and diarrheal illnesses at level of donor selection, and poor adherence to standard antiseptic measures prior to blood collection.

The rate of contamination was higher among platelet concentrate than packed RBC units, $38 \%$ vs $28 \%$. This could be explained by storage conditions, as platelets are stored between $20-24{ }^{\circ} \mathrm{C}$, which provide a favourable environment (Eder et al., 2017; Makuni, 2015).

Bacillus subtilis was the predominant, followed by Staphylococcus epidermidis, Escherichia coli, Proteus mirabilis and Pseudomonas aeruginosa. Our finding were as
Agzie et al. (2019), as their findings showed that the majority were Gram-positive bacteria. However, this study, consisting of findings of most of the studies conducted in African countries as Kenya (Hassall et al., 2009), Nigeria (Aboderin, 2017) and Ghana (Adjei et al., 2009).

The requirement to assess the rate and spectrum of blood product contaminations is mandatory. The clinical impact of the transfusion of contaminated blood products on patients, particularly immune-compromised secondary to haematological malignancies and chemotherapy assessment is the goal. Blood banks must be notified about the necessary measures to control the transmission of infection and contamination of blood components.

\section{CONCLUSION}

Bacterial contamination is common and presented at a high rate. Gram-positive bacteria were the most predominant, and this attributed to poor skin cleansing and antiseptic techniques used prior to donor blood collection.

\section{REFERENCES}

Adjei, AA, Kuma, GK, Tettey, Y, Ayeh-Kumi, PF, Opintan, J, Apeagyei, F, Ankrah, JO, Adiku, TK \& Narter-Olaga, EG 2009, 'Bacterial contamination of blood and blood components in three major blood transfusion centers, Accra, Ghana', Japanese Journal of Infectious Diseases, vol. 62, no. 4, pp. 265-269.

Agzie, M, Niguse, S, Tsegay, E, Kahsay, G \& Mahmud, MA 2019,
'Bacterial contaminants of stored blood and blood components ready for transfusion at blood banks in Mekelle, Northern Ethiopia', BMC Research Notes, vol. 12, no. 1, pp. 1-6.

Aloysius, GM, Joel, B, Apecu, R, II, BY \& Byarugaba, F 2013, 'Bacterial contamination of blood and blood components at Mbarara Regional Blood Bank in Rural 
South Western Uganda', Advances in Infectious Diseases, vol. 3, pp. 205-209.

Arewa, O 2009, 'One year clinical audit of the use of blood and blood components at a tertiary hospital in Nigeria', Nigerian Journal of Clinical Practice, vol. 12, no. 4, pp. 429-433.

Bolarinwa, RA, Aboderin, OA, Odetoyin, BW \& Adegunloye, AB 2011, 'Bacterial contamination of blood and blood components in a tertiary hospital setting in Nigeria', International Journal of Infection Control, vol. 7, no. 1, pp. 1-6.

Brecher, ME \& Hay, SN, 'Bacterial contamination of blood components', Clinical Microbiology Reviews, vol. 18, no. 1, pp. 195-204.

Cawley, C, McDonald, C, Ancliff, S, Roy, A, MacLennan, S, Brant, L, Pichon, B \& Brailsford, S 2011, 'Early recognition and reporting of suspected bacterial contamination may prevent transfusion transmission of infection by associated units', Transfusion Medicine, vol. 21, no. 1, pp. 70-72.

Eder, AF, Dy, BA, DeMerse, B, Wagner, SJ, Stramer, SL, O'Neill, EM \& Herron, RM 2017, 'Apheresis technology correlates with bacterial contamination of platelets and reported septic transfusion reactions', Transfusion, vol. 57, no. 12, pp. 29692976.

Hassall, O, Maitland, K, Pole, L, Mwarumba, S, Denje, D, Wambua, K, Lowe, B, Parry, C, Mandaliya, K \& Bates, I 2009, 'Transfusion complications: bacterial contamination of pediatric whole blood transfusions in a Kenyan hospital', Transfusion, vol. 49, no. 12, pp. 2594-2598.

Kuehnert, MJ, Roth, VR, Haley, NR, Gregory, KR, Elder, KV, Schreiber, GB, Arduino, MJ, Holt, SC, Carson, LA, Banerjee, SN \& Jarvis, WR 2001, 'Transfusion-transmitted bacterial infectionin the United States, 1998 through 200o', Transfusion, vol. 41, no. 12, pp. 1493-1499.

Makuni, Ngonidzashe, Clifford Simango \& Rooyen, T, Mavenyengwa, 'Prevalence of bacterial contamination in blood and blood products at the National Blood Service Zimbabwe', The Journal of Infection in Developing Countries, vol. 9, no. 4, pp. 421-424.

Perez, P, Salmi, LR, Folléa, G, Schmit, JL, De Barbeyrac, B, Sudre, P, Salamon, R \& Bacthem Group the French Haemovigilance Network, 'Determinants of transfusionassociated bacterial contamination: results of the French BACTHEM case - control study', Transfusion, vol. 41, no. 7 , pp. 862-872.

Samia, A, Ghada, A \& Fatama, H 2014, 'Rapid detection of bacterial contamination in platelet concentrates, by polymerase chain reaction and DNA sequencing in comparison to conventional automated culture', International Journal of Current Microbiology and Applied Sciences, vol. 3, no. 4, pp. 38-52.

Wagner, SJ, Friedman, LI \& Dodd, RY 1994, 'Transfusionassociated bacterial sepsis', Clinical Microbiology Reviews, vol. 7, no. 3, pp. 290-302.

Walther-Wenke, G 2008, 'Incidence of bacterial transmission and transfusion reactions by blood components', Clinical Chemistry and Laboratory Medicine (CCLM), vol. 46, no. 7, pp. 919-925.

Williamson, LM, Lowe, S, Love, EM, Cohen, H, Soldan, K, McClelland, DBL, Skacel, P \& Barbara, JAJ 1999, 'Serious hazards of transfusion (SHOT) initiative: analysis of the first two annual reports', Bmj, vol. 319, no. 7201, pp. 16-19. 